\title{
School placement decisions in Luxembourg: Do teachers meet the Education Ministry's standards?
}

\author{
Florian Klapproth, Sabine Glock, Matthias Böhmer, Sabine Krolak-Schwerdt, Romain Martin \\ University of Luxembourg
}

\begin{abstract}
In Luxembourg, the assignment of primary-school students to one of the tracks in secondary school is regulated by the Luxembourgish Ministry of Education. These regulations entail four criteria according to which decisions about the assignment should be made. With the study at hand, it was examined whether teachers meet these four criteria when assigning students to either the academic track or the vocational track of secondary school. We conducted multi-level regression analyses on a representative sample of 2,731 Luxembourgish primary school $6^{\text {th }}$ graders. Six major results were obtained. (1) Students' school marks in language courses were most predictive for school placement decisions. (2) School marks were on average of more predictive value than were scores of standardized scholastic achievement tests. (3) Working and learning habits of the students played a role when teachers made their school placement decisions. (4) There was a strong positive relationship between the teachers' placement decisions and the parents' schooling preferences. (5) The socio-economic background of the students did substantially affect school placement decisions. (6) Even when achievement variables were controlled for, migration background of students contributed significantly to teachers' school placement decisions.
\end{abstract}

\section{Introduction}

In school systems with stable tracks, as they are common in some European countries like Germany, Austria, Switzerland, and Luxembourg, primary school teachers are required to make decisions by which students are allocated to a certain track of secondary school. In Luxembourg, this decision is taken by a decision council at the end of sixth grade of primary school. The council is composed of the students' primary school teacher and of secondary school teachers, assisted by the local school inspector. Students are oriented to one of three hierarchical tracks that constitute the Luxembourgish secondary school, which are the Enseignement Secondaire Classique
(ESC; the highest track), the Enseignement Secondaire Technique (EST; the middle track), and the Régime Préparatoire (RP; the lowest track). Students are generally oriented towards the ESC when they have a flawless achievement profile. An achievement profile showing difficulties in one or more subjects generally leads to on orientation towards the EST track, while students with major learning difficulties are oriented towards the RP track.

Most of the Luxembourgish primary school students (about $95 \%$ ) are oriented towards either the highest track (the academic track) or the middle track (the vocational track) [1]. The academic track offers students the possibility to obtain the general qualification for university entrance, whereas students attending the vocational track in general receive certifications of eligibility for studying at appliedsciences universities or for non-academic professions.

The decision of the council is mandatory. Therefore, it strongly determines the future academic career of each student. According to regulations published by the Luxembourgish Ministry of Education [2], the students' level of achievement in primary school ought to be the main determinant of the school placement decisions made by the council. Indicators of achievement are students' school marks in the main curricular areas (French, German, and Mathematics) as well as scores of standardized scholastic achievement test that are administered in the main curricular areas in sixth grade of primary school. Moreover, teachers are required to assess the students' working and learning habits. Finally, teachers ought to consider the parents' requests for future schooling of the students.

However, as has been shown in a variety of studies, school placement decisions are not only determined by obligations of the corresponding authority, but are also affected by variables of the students' social background [3, 4, 5].

In the following, we will distinguish between variables that are explicitly part of the Luxemburgish Education Ministry's standards concerning the assignment of primary school students to one of the tracks of secondary school (school marks, test scores, working and learning habits as well as parents' 
requests), and variables that are related to the social background of the students and which are by definition not part of the regulations. Below, we will present major results of studies that previously had examined the impact of these variables on placement decisions in Germany or Switzerland.

According to most studies that investigated predictors of school placement decisions, it has been shown that performance-related variables like school marks or test scores are by far most predictive for school placement decisions. Of these variables, school marks explain the largest amount of variance in placement decisions [6,7,4], followed by results of standardized achievement tests [5, 6, 7, 8, 9]. Additionally, working and learning habits are also predictive for the selection of the students, particularly if both school marks and test scores do not allow for a definite decision. In some countries and federal states, parents are given the opportunity to advance their opinion regarding the track their child should attend. As has been shown in some studies, parental aspirations may indeed affect placement decisions. For instance, if parents wish to have their child oriented to the highest track in secondary school, the child is more likely to be assigned to the highest track than if parents want their child to attend a lower track [10].

However, school placement decisions do not only reflect students' academic achievements, but are also affected by the students' social background [3, 4, 5]. In particular, their socio-economic status and their nationality have often been shown to have an effect on teachers' placement decisions. For instance, students with families showing rather low income are less frequently recommended for the highest track than students with high-income parents [6, 7]. Furthermore, students having a migration background are reported to be more likely to be oriented to the lowest track and less likely to be oriented to the highest track than students without migration background [11].

Results of the PISA 2006 study [12] also show that in Luxembourg children with migration background and children with low-income parents appear to be disadvantaged with respect to the school placement decisions they obtain. For example, only $19 \%$ of the students who have a migration background and just about $12 \%$ of the students with low-income parents attend the highest track (compared to $45 \%$ of the students without migration background, and $59 \%$ of the students with middle- or high-income parents).

\section{Objectives and hypotheses of the study}

In Luxembourg, the assignment of primary school students to one of the tracks in secondary school is regulated by the Luxembourgish Ministry of Education.
These regulations entail four criteria according to which decisions about the assignment should be made. These criteria are (1) school marks in the main subjects of the curriculum (French, German, Mathematics), (2) results of standardized scholastic achievement tests which are obtained from the same curricular fields (French, German, Mathematics), (3) the working and learning habits of a student, and (4) the parents' opinions about the future school type their child should attend.

With the study at hand, it was our primary aim to examine whether or not school placement decisions in Luxembourg meet these four criteria. In particular, we investigated to what extent variables related to the four criteria actually predict individual school placement decisions.

As we know from previous research, school placement decisions are not only determined by obligations of the corresponding authority, but are also affected by variables representing the students' social background. Therefore, the second aim of the present study was to examine whether the students' social background (i. e., nationality and the socio-economic status of the students) plays a role in orienting primary school students to secondary school in Luxembourg.

Moreover, we were interested in the relative weights with which performance related variables and variables of the social background do affect school placement decisions. We assumed that even in the event of a substantial contribution of the social background to school placement decisions, the level of students' achievement should play the major role when teachers recommend their students for a track of secondary school.

With respect to achievement-related variables (school marks, test scores, working and learning habits), we assumed that higher individual achievement should correspond with teachers' recommendations for higher tracks. In particular, high achievements should increase the likelihood for a student to be assigned to the academic track, whereas rather low achievements should increase the likelihood to be oriented to the vocational track. Concerning the variables of the students' social background, we hypothesized that students without migration background or students with higher-income parents were more likely to receive a recommendation for the academic track than students with migration background or students with lower-income parents. With respect to parents' preferences for future schooling, we assumed that students are more likely to be recommended for the academic track if their parents do also prefer the academic track. However, if they prefer the vocational track, the likelihood for a 
recommendation for the academic track should decrease accordingly.

\section{Method}

In the following, the sample, the variables, and the design used for analyses are described.

\subsection{Sample and Variables}

The data set we report here is part of a study that has been conducted by the EMACS research unit of the University of Luxembourg between the years 2008 and 2011, and that was supported financially by the Fonds National de la Recherche Luxembourg (C08/LM/02). Since the vast majority of Luxembourgish students are oriented either towards the academic track or towards the vocational track (and only a few are oriented towards the lowest track), we were interested in examining how the teachers' decision between both alternatives was affected by the variables we considered important for placement decisions. Thus, we excluded those students who were recommended for the lowest track for the following analyses. We obtained school placement decisions recommending either the academic track or the vocational track of secondary school of a total of $N=2,7316^{\text {th }}$ graders (49.1\% males) of Luxembourgish primary schools. The students were distributed to 211 classes of a total of 104 primary schools. $42.5 \%$ of the students were recommended for the academic track. Mean age of the students at the time of data collection was 12.5 years $(S D=0.52)$. The mean ISEI value was $51.4(S D=16.9)$ which corresponded to a middle-income clerical worker [13] and which fits well the parameters of the Luxembourgish ISEI distribution found in PISA 2009 [14]. Almost two-thirds of the students were Luxemburgish (66.0\%), whereas more than half of the remaining students were Portuguese (18.7\%).

In order to estimate the weight by which each variable that was relevant for our hypotheses affected school placement decisions, we conducted multi-level regression analyses. The following variables were used as predictors in multi-level regression analyses: the $6^{\text {th }}$ grade averaged school marks of the main subjects (French, German, Mathematics), test scores of standardized scholastic achievement tests that had been run for the main curricular fields at the end of $6^{\text {th }}$ grade (French, German, Mathematics), the working and learning habits of the students, the socio-economic status of the students' parents (measured by the ISEI scale), the students' migration background (assessed by students' nationality), and the parents' preferences for future schooling of their children.

\subsection{Statistical Design}

We conducted multi-level regression analyses, using the HLM 6 software [15] in order to capture the hierarchical structure of the school wherein students are nested in classes. Moreover, multi-level regression analyses allows for more precise estimations of regression weights than do standard regression analyses, if a hierarchical structure is present in the data set. The criterion was the teachers' school placement decision, which contained the values "recommended for the academic track" versus "recommended for the vocational track". Consequently, logistic multi-level regression analyses were conducted.

Students' nationality was coded as two dichotomous dummy variables with Luxembourgish students forming the reference group. The first dummy variable represented Portuguese students, the second dummy variable represented students of other foreign nationalities. Portuguese students were coded as a separate group since the Portuguese are the largest national minority in Luxembourg.

Working and learning habits were assessed by using a rating scale which contained 14 items. Prior to testing our hypotheses, results of the rating scale had undergone factor analysis. It turned out that most of the rating scale's variance was explained by three orthogonal factors, of which the first corresponded to students' learning motivation, the second to the students' reliability and accuracy, and the third to the students' social behaviours. Since only the first two factors contributed to working and learning habits, we decided to discharge items mainly loading on the third factor. Hence, in the following regression analyses, two variables were considered as predictors, one representing the students learning motivation, whereas the other represented the students' reliability and accuracy.

We replaced missing values of all metric variables by means of multiple imputation [16] prior to regression analyses.

The predictors were entered into the regression models according to our hypotheses. All regression models were random intercept models, which were estimated with full maximum likelihood. To achieve comparability between the predictors' weights, we made z-transformations for each predictor prior to regression analysis.

\section{Results}

To test the hypotheses, multi-level logistic regression analyses were conducted, with "school 
Table 1. Odds ratios of multi-level regression analyses, separated for eight models (M1-M8)

\begin{tabular}{|c|c|c|c|c|c|c|c|c|}
\hline Predictors & $M 1$ & $M 2$ & $M 3$ & $M 4$ & $M 5$ & $M 6$ & $M 7$ & $M 8$ \\
\hline Intercept & $0.07^{\star \star \star}$ & 0.06 *** & $0.05^{\star \star \star}$ & $0.03 * * \star$ & 0.68 *** & $0.66^{\star \star \star}$ & $0.63^{\star \star \star}$ & 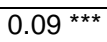 \\
\hline Marks German & $15.51^{\star \star \star}$ & $7.23^{\star \star \star}$ & $6.79 * * *$ & $4.14^{* \star \star}$ & & & & 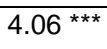 \\
\hline Marks French & $19.27^{\star \star \star}$ & $11.45^{\star \star \star}$ & 11.59 *** & $8.26^{* \star \star}$ & & & & $8.98^{\star \star \star}$ \\
\hline Marks Mathematics & $9.19^{\star \star \star}$ & $3.08^{\star \star \star}$ & $2.79 * \star \star$ & $2.90^{* * *}$ & & & & 2.16 *** \\
\hline Test German & & $4.64^{\star \star \star}$ & $4.63^{\star \star \star}$ & $3.19^{* \star *}$ & & & & 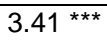 \\
\hline Test French & & $3.62^{\star \star \star}$ & $3.63^{\star \star \star}$ & $4.59^{* \star \star}$ & & & & 3.12 *** \\
\hline Test Mathematics & & $4.62^{\star \star \star}$ & $4.95^{\star \star \star}$ & $6.24^{* \star \star}$ & & & & 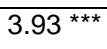 \\
\hline $\begin{array}{l}\text { Achievement } \\
\text { Motivation }\end{array}$ & & & 0.98 & 0.94 & & & & 0.97 \\
\hline Reliability/Accuracy & & & $1.35^{*}$ & $1.66^{\star \star}$ & & & & $1.37^{*}$ \\
\hline Migration: Port. & & & & & 0.53 *** & & 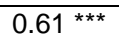 & $0.73^{\star \star}$ \\
\hline Migration: else & & & & & 0.79 *** & & 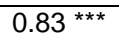 & 0.82 \\
\hline ISEI & & & & & & 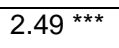 & $2.30 * \star \star$ & 1.14 \\
\hline $\begin{array}{l}\text { Parents' } \\
\text { Preferences }\end{array}$ & & & & $8.93^{\star \star \star}$ & & & & \\
\hline Deviance & 6117 & 5873 & 5868 & 5583 & 8460 & 8256 & 8160 & 5888 \\
\hline
\end{tabular}

Note: ${ }^{* * *} \mathrm{p}<.001 ; * * \mathrm{p}<.01 ; * \mathrm{p}<.05$.

placement decision” as dichotomous criterion. Table 2 shows the results (odds ratios) obtained from multilevel regression analyses.

First, it was examined to what extent variables related to the standards proposed by the Luxemburgish Ministry of Education actually predict individual school placement decisions. In particular, we tested whether achievement variables (school marks, test scores, and learning and working habits) and parents' preferences contributed significantly to variation of school placement decisions. Model 1 entailed the $6^{\text {th }}$ grade school marks of the main subjects (French, German, and Mathematics). As expected, all predictors exerted a significant impact on teachers' placement decisions. Notably, achievement in languages was of more importance than achievement in Mathematics.

As Model 1 demonstrates, the chance to receive a recommendation for the highest track was raised by factor 19.3 when school marks in French increased by one unit. Note that one unit equals one standard deviation of the predictor, for prior to regression analysis all predictor variables had been transformed into z-scores. In Model 2, we supplemented previous predictors with scores of standardized scholastic achievement tests. As a consequence, the weights of school marks decreased substantially. Compared to school marks, test scores played on average a less important, yet significant role for school placement decisions.
Model 3 entailed-in addition to school marks and test scores-the values of achievement motivation as well as of reliability and accuracy of the students as indicators of their working and learning habits. Whereas reliability/accuracy actually played a role in teachers' placement decisions, achievement motivation did not. The pattern of results did not change in essence when parents' preferences for schooling were added to the model (Model 4). Moreover, as hypothesized, parents' preferences were closely related to school placement decisions. If parents preferred the academic track, the students' chance to be oriented to the academic track was highly increased.

In the following models (Model 5 to 7), variables of the students' social background served as predictors for school placement decisions. In Model 5 and 6, migration background or socio-economic status, respectively, was used as the only predictor. As hypothesized, migration background turned out to be a significant predictor for school placement decisions. Students were less likely to get an academic-track recommendation if they were not Luxemburgish. This was true for both Portuguese students and students of other nationalities. However, the probability to be oriented to the academic track seemed to be slightly lower for Portuguese students than for students of other nationalities. Moreover, in line with the hypothesis stated, socio-economic status was a significant predictor for school placement decisions (Models 6 and 7). 
With Model 8, we examined whether the effect of students' social background on school placement decisions would disappear if indicators of students' achievements were controlled for. Surprisingly, migration background turned out to be still a significant predictor for placement decisions.

The deviances depicted in Table 2 indicate the goodness of fit of each model, with smaller deviances representing better fit. Chi-Square tests were performed in order to test differences between deviances for significance, and revealed significant results in comparisons of all models, except for the difference between Model 2 and Model 3.

\section{Discussion}

This study addressed two research questions. First, we examined whether the standards for orienting primary school students to one of the different tracks of secondary school, which were proposed by the Luxemburgish Ministry of Education, were actually realized. These standards resort to the students' school marks in the main subjects, test scores of standardized scholastic achievement tests, working and learning habits, and parents' preferences for the type of schooling their children should receive. Since it has often been found that school placement decisions are not only affected by the students' achievement in school, but also by factors that represent their social background, we secondly investigated whether the students' nationality, or their socio-economic status was related to the school placement decisions.

Six major results were obtained with this study. First, of all variables analysed, school marks of the students obtained in language courses (French, German) were most predictive for school placement decisions. This result is in accordance with findings previously obtained in studies with samples of German students and teachers [6, 7]. Particularly, the large weight allocated to school marks in French may reflect the fact that French is one of the main languages of instruction in Luxembourgish secondary school. Since also achievements in German exerted a large weight, one can conclude that competences in languages are one of the most important factors for teachers to decide on which school type a student should attend in secondary school.

Second, school marks were on average of more predictive value than were scores of standardized scholastic achievement tests (except Mathematics). In other words, teachers obviously did prefer school marks over test scores when making decisions with respect to future schooling of primary school students. We think that this result might come along with the predominance of school marks during instruction and teaching. Furthermore, it could also be the case that teachers may mistrust results of standardized tests as these results do capture curricular contents only partially. Again, this result is a replication of results yielded previously and elsewhere [9].

Third, working and learning habits of the students played a role when teachers made their school placement decisions. Apparently, students' reliability and accuracy were of more importance for teachers than their achievement motivation. One possible reason for the difference of weights between both indicators of students' learning and working habits might lie in the fact that achievement motivation was highly correlated with school marks and test scores, so that the small weight obtained for achievement motivation was due to the large weights obtained for school marks and test scores.

Fourth, there was a strong positive relationship between the teachers' placement decisions and the parents' schooling preferences. We think that this relationship might have been resulted from similar, but independent evaluations of the students by both teachers and parents, since both had access to information about the students' academic achievements. However, it is also possible that parents often simply adopted teachers' evaluations.

Fifth, the socio-economic background of the students, assessed by the ISEI, substantially affected school placement decisions. This finding confirms our hypothesis and partially agrees with findings of several studies conducted in Germany, which showed that higher socio-economic status corresponded with higher probability of receiving a highest-track recommendation, even when achievement variables were entered into regression analyses $[6,17]$. However, when achievement variables were considered simultaneously, the effect of the socio-economic background of the students diminished, which indicates that socio-economic background was highly correlated with performance in school.

Sixth, inequalities in school placement decisions made in Luxembourg do exist with respect to students' nationality. Even when controlled for variation of achievement variables, migration background of students contributed significantly to teachers' school placement decisions, with students not originating from Luxembourg having lower probabilities to get a recommendation for the academic track than Luxemburgish students. Most previous studies that investigated predictors of school placement decisions elsewhere found a significant effect of migration background on placement decisions. However, these effects almost always disappeared when achievement predictors were added to regression models $[4,5,8,18]$ 
which points to the fact that nationality and achievement were highly confounded. More precisely, in those studies, students with migration background got a recommendation for one of the lower tracks because they obtained lower school marks (for whatever reason). In Luxembourg, however, it appears to be the case that non-Luxemburgish students were more likely to be recommended for the vocational track despite their school marks and test scores.

\section{Conclusion}

One of the objectives of the present study was to examine whether the factors that actually affect school placement decisions match the factors that had been proposed by the Luxembourgish Ministry of Education as a standard for making placement decisions. The results of this study showed that teachers did their job well with respect to these standards. However, as we could also show, teachers additionally used attributes of the students that were not considered as criteria for placement decisions. These attributes were the students' socio-economic status and their nationality. Even if the students' academic achievement was considered simultaneously, nationality of the students persisted to affect school placement decisions, with native students being more likely to be oriented to the academic track of secondary school than immigrant students. A possible explanation of this result refers to the group within which placement decisions in Luxembourg are made. This group usually consists of teachers and school inspectors. Research from social psychology suggests that group decisions may suffer from a diffusion of responsibility between group members. Diffusion of responsibility means that each member of a group may not feel as much pressure to make the "right" decision since the responsibility for the decision is thought to be shared among all of those present [19, 20]. Moreover, it has been shown that social stereotypes are more likely to guide the information processing in group decisions than in individual decisions [21]. Social stereotypes that have been identified in educational contexts are the students' gender, the socio-economic status as well as their nationality $[7,22]$. Therefore, it seems to be at least possible that the group situation wherein placement decisions are made does foster the influence of social stereotypes on the decision outcome.

The results obtained may be of importance for all individuals and organisations being engaged in education and teaching in Luxembourg and abroad, particularly with respect to the weight nationality seems to have in school placement decisions. However, it should be noted that regression analyses do not allow for causal conclusions. Inclusion or exclusion of variables serving as predictors might change the weights of all remaining predictors, and might even reduce their predictive value to insignificance. Therefore, further analyses are still needed.

\section{References}

[1] P. Reding, Le passage primaire-postprimaire: Analyse de la procedure d'orientation. [The transition from primary school to secondary school: An analysis of the tracking procedure]. Ministère de l'Education Nationale, de la Formation Professionelle et des Sport, Luxembourg, 2006.

[2] M. Thill, La nouvelle procédure de passage de l'enseignement primaire (public et privé) vers l'enseignement secondaire et secondaire technique: Resultats des conseil d'orientation et des procédures de recours [The new transition from primary to secondary school : Results of the tracking council and the procedure of adminstrative appeals]. Ministère de l'Education Nationale, de la Formation Professionelle et des Sport, SCRIPT, Luxembourg, 2001.

[3] J. Baumert, and G. Schümer, "Familiäre Lebensverhältnisse, Bildungsbeteiligung und Kompetenzerwerb im nationalen Vergleich.” In Deutsches PISAKonsortium (Hrsg.), PISA 2000 - Die Länder der Bundesrepublik im Vergleich (pp. 159-202). Opladen, Germany: Leske \& Budrich, 2002.

[4] T. C. Stubbe, and W. Bos, "Schullaufbahnempfehlungen von Lehrkräften und Schullaufbahnentscheidungen von Eltern am Ende der vierten Jahrgangsstufe”, Empirische Pädagogik, 22, Verlag Empirische Pädagogik, Landau, Germany, 2008, pp. 49-63.

[5] J. Tiedemann, and E. Billmann-Mahecha, "Zum Einfluss von Migration und Schulklassenzugehörigkeit auf die Übergangsempfehlung für die Sekundarstufe I”, Zeitschrift für Erziehungswissenschaft, 10, VS Verlag, Wiesbaden, Germany, 2007, pp. 108-120.

[6] K.-H. Arnold, W. Bos, P. Richert, and T. C. Stubbe, "Schullaufbahnpräferenzen am Ende der vierten Klassenstufe”. In W. Bos, S. Hornberg, K.-H. Arnold, G. Faust, L. Fried. E.-M. Lankes, K. Schwippert and R. Valtin (Hrsg.), IGLU 2006. Lesekompetenzen von Grundschulkindern in Deutschland im internationalen Vergleich (pp. 271-297). Münster, Germany: Waxmann, 2007.

[7] W. Bos, A. Voss, E.-M. Lankes, K. Schwippert, O. Thiel, and R. Valtin, "Schullaufbahnempfehlungen von Lehrkräften für Kinder am Ende der vierten Jahrgangs- 
stufe”, In W. Bos, E.-M. Lankes, M. Prenzel, K. Schwippert, R. Valtin, and Walther, G. (Hrsg.), IGLU - Einige Länder der Bundesrepublik Deutschland im nationalen und internationalen Vergleich (pp.191-228). Münster, Germany: Waxmann, 2004.

[8] C. Kristen, "Ethnische Diskriminierung in der Grundschule? Die Vergabe von Noten und Bildungsempfehlungen”, Kölner Zeitschrift für Soziologie und Sozialpsychologie, 58, VS Verlag, Wiesbaden, Germany, 2006, pp. 79-97.

[9] A. Milek, O. Lüdtke, U. Trautwein, K. Maaz, and T. C. Stubbe, "Wie konsistent sind Referenzgruppeneffekte bei der Vergabe von Schulformempfehlungen? Bundeslandspezifische Analysen mit Daten der IGLUStudie”, Zeitschrift für Erziehungswissenschaft, 12, VS Verlag, Wiesbaden, Germany, 2009, pp. 282-301.

[10] R. Becker, "Klassenlage und Bildungsentscheidungen. Eine empirische Anwendung der Wert-Erwartungstheorie”, Kölner Zeitschrift für Soziologie und Sozialpsychologie, 52, VS Verlag, Wiesbaden, Germany, 2000, pp. 450-474.

[11] M. Neumann, A. Milek, K. Maaz, and C. Gresch, "Zum Einfluss der Klassenzusammensetzung auf den Übergang von der Grundschule in die weiterführenden Schulen”, In Bundesministerium für Bildung und Forschung, K. Maaz, J. Baumert, C. Gresch \& N. McElvany (Hrsg.), Der Übergang von der Grundschule in die weiterführende Schule: Leistungsgerechtigkeit und regionale, soziale und ethnischkulturelle Disparitäten, Bildungsforschung Band 34 (pp. 229-252). Bonn, Berlin: BMBF, 2010.

[12] R. Burton, M. Reichert, M. Brunner, U. Keller, B. Boehm, and R. Martin, Migrationshintergrund und sozioökonomischer Status der Schülerinnen und Schüler [Migration background and socioeconomic status of students]. In MENFP and EMACS (Eds.), PISA 2006 - Nationaler Bericht Luxemburg (pp. 3245). MENPF et Université du Luxembourg, Luxembourg, 2007.

[13] H. B. G Ganzeboom, P. M. De Graaf, and D. J. Treiman, “A standard international socio-economic index of occupational status”, Social Science Research, 21, Elsevier, Amsterdam, 1992, pp. 1-56.

[14] T. Ehmke, and N. Jude, "Soziale Herkunft und Kompetenzerwerb” In E. Klieme et al. (Hrsg.), PISA 2009. Bilanz nach einem Jahrzehnt (pp. 231-254). Münster, Germany: Waxmann, 2010.
[15] S. Raudenbush, A. Bryk, Y. F. Cheong, R. Congdon, and M. Toit, HLM 6. Hierarchical linear and nonlinear modelling. Lincolnwood, IL: Scientific Software International, 2004.

[16] J. L. Schafer, NORM 2.03 for Windows 95/98/NT [Computer Software], 2000.

[17] K. Maaz, and G. Nagy, "Der Übergang von der Grundschule in die weiterführenden Schulen des Sekundarschulsystems: Definition, Spezifikation und Quantifizierung primärer und sekundärer Herkunftseffekte”, Zeitschrift für Erziehungswissenschaft, 12, VS Verlag, Wiesbaden, Germany, 2009, 153-182.

[18] M. Schmitt, “Die Bedeutung von sozialer Herkunft und bundeslandspezifischen Übergangsregelungen für die Grundschulempfehlung”. In E.-M. Lankes (Hrsg.), Pädagogische Professionalität als Gegenstand empirischer Forschung (pp. 111-121). Münster, Germany: Waxmann, 2008.

[19] B. Latane, and J. M. Darley, "Group inhibition of bystander intervention in emergencies”, Journal of Personality \& Social Psychology, 10, APA, Washington, 1968, pp. 215-221.

[20] M.-P. Zanna, and G. N. Sande, (1987). "The effects of collective actions on the attitudes of individual group members: A dissonance analysis.” In M. P. Zanna, J. M. Olson, and C. P. Herman (Eds.), Social influence: The Ontario Symposium, Vol. 5 (pp. 151-163). Hillsdale, NJ: Erlbaum, 1987.

[21] J. S. Lerner, and P. E. Tetlock, “Accountability and social cognition”, Encyclopedia of Human Behavior, 1, Elsevier, Amsterdam, 1994, pp. 1-10.

[22] L. Jussim, J. Eccles, and S. Madon, "Social perception, social stereotypes, and teacher expectations: Accuracy and the quest for the powerful self-fulfilling prophecy", Advances in Experimental Social Psychology, 28, Elsevier, Amsterdam, 1996, pp. 281388. 